\title{
Majority values of school biological education in the context of education for sustainable development
}

\author{
Elena Komarova ${ }^{1, *}$, and Tatiana Starova ${ }^{2}$ \\ ${ }^{1}$ Immanuel Kant Baltic Federal University, Kaliningrad, 236041, Russian Federation \\ ${ }^{2}$ Kryvyi Rih State Pedagogical University, Kryvyi Rih, 50086, Ukraine
}

\begin{abstract}
The idea of the study is that the value potential of the subject is a fundamental element of the knowledge system as part of the realization of the idea of sustainable development in education. The basis of the study used the classification of value categories proposed by Milton Rokeach in 1979. We found that in the main school, the content of the subject "Biology" is primarily aimed at forming ideas about terminal values - "life", "health", "nature"; in high school - about terminal values "life", "health", as well as instrumental values - "perseverance". The value ideas of a biology teacher are one of the key factors in the formation of students' value ideas. In the structure of value representations of biology teachers, the three leaders are orientations towards terminal values. We have put forward the assumption that there is a dissonance between the value ideas of respondents and the values that the school biology course is aimed at forming an idea about.
\end{abstract}

\section{Introduction}

At the 70th session of the UN General Assembly, the 2030 Agenda for Sustainable Development was adopted. It includes 17 new global goals that will be included in the subject field of education for sustainable development [1].

According to the Incheon Declaration [2], education is considered as the main driving force for transforming people's lives and achieving sustainable development goals. We are talking about the development of skills, value orientations and behaviours that enable citizens to lead a full, healthy life, make informed decisions and respond to local and global challenges through education for sustainable development and education in the spirit of global citizenship [1].

Education for sustainable development is an international vector of education and enlightenment of a person throughout his life, which is implemented in the interests of human capital development, in order to preserve the cultural and natural heritage of the planet for generations [5].

There are several models for the implementation of education for sustainable development: natural science, interdisciplinary and school-wide [3]. In the framework of the natural science approach, education for sustainable development is considered the successor to environmental education, i.e. teaching the subject "Ecology" [3].

On a global scale, changes in educational systems aimed at adopting the idea of education for sustainable development have been taking place since the early 2000s [1;3].
The transition to new state educational standards and programs in high school in Ukraine from the academic year 2018/2019 was marked by dramatic changes in the content of the natural sciences educational sector and the biology subject in particular.

Firstly, the name of the subject has changed "Biology" has turned into "Biology and Ecology".

Secondly, the field practicum was removed from the program.

Thirdly, the principle of functionality has been applied to structuring the content of the subject to replace the principle of hierarchy.

The last two changes require clarification. A field practicum in the previously existing program was provided for a profile level of the subject study, included topics of environmental content and was aimed at developing practical skills of high school students to use bioecological research methods. The principle of hierarchy reflected the phylogenetic sequence of the emergence of living levels, corresponded to the stages of cognitive activity of the student in the formation of highlevel generalizations: "biosphere", "noosphere", "technosphere", "living matter", V .I. Vernadskyi and others.

The above-mentioned changes are carefully considered as the movement towards the implementation of the idea of sustainable development in school biological education. Effectiveness of the change can be measured over time.

Today, education for sustainable development has two methodological problems [4].

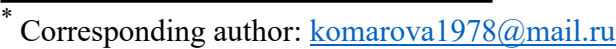


The first is connected with scientific foundations, since a classical scientific school cannot fully meet the principle of scientificness in modern conditions [4].

The second methodological problem is the futuristic prognostic nature of education. The growing capabilities of information technology in an irrepressible progression require students to learn how to predict the future steps ahead.

Therefore, it is relevant not only to teach to analyze and draw conclusions, but to predict, envisage the future, and model the activity in the long run. Another difficulty in the formation of education for sustainable development is called the blurring of its content: knowledge, methods of activity and value-semantic attitudes [5].

The concept of "sustainable development" is twofold.

On the one hand, sustainability provides stability, fundamentality, in a certain sense stagnation. On the other hand, development is based on transformation, change, improvement.

Out of this we conclude that a system that is in a state of sustainable development includes unchanged or hardly changed fundamentals and permanent deviations, summarizing as a result in a new quality. What constitutes an unshakable foundation, and what is subject to changes in the framework of science education for sustainable development in general and biological in particular, these questions have to be answered.

The effectiveness of any educational system is evaluated according to the final result. According to the culturological theory of the education content, the results of education are knowledge, reproductive experience, experience in creative activity, and experience of an emotional-value attitude to the world [6]. The need to address just this theory when designing the content of education for sustainable development is indicated in a number of studies [5].

A school subject is a didactically adapted system of scientific knowledge about the world and a person's place in it. The volume of scientific knowledge is growing exponentially, therefore knowledge is the most dynamic element of the system.

In the framework of the study, we consider the experience of an emotional-value attitude to the world as the most constant, long-forming and system-forming element of the knowledge system. We consider the formation of an emotional-value component by means of school biology as one of the strategic goals of education for sustainable development.

The experience of an emotional-value attitude to the world involves the formation a schoolchild's set of value ideas that guide him in the present and future. At the same time, a personal experience of an emotional-value attitude to the world is formed [7].

The value ideas that make up the personal experience act as regulators of behaviour and factors in the choice of a particular model of action. At the same time, they are the result of a person's assimilation of social and cultural-historical experience.

The selection of the content of a school subject aimed at the formation of value ideas among schoolchildren is based on the value potential of biological science: its cultural and historical component [8], current and future prospects for the development of not only basic science, but science as a whole as part of culture.

The transformation of the value potential of a subject into value ideas of students occurs with the direct participation of a teacher who acts as a mediator between the content of the subject and the emotional and value sphere of the student.

The process has a subjective colouring, because it is based, firstly, on the teacher's understanding of the value meanings of the educational process in general and the educational process in biology in particular, and secondly, on the teacher's personal value ideas.

At different stages of ontogenesis, different values have unequal relevance, which is due to a change in leading human activities.

The chronological principle of constructing a system of values is that values of an earlier age acquire a subordinate position with respect to values of a later period [9].

In the context of science education for sustainable development, such a change has other reasons - there is a constant change in the substantial and process content of academic subjects. These changes are caused not only by regular age-related changes in the cognitive activity of students and the concentration of the subject content around generalizations of science in high school compared with the main school in one cycle, but also by a change in the approaches to the selection and structuring of educational content from cycle to cycle in historical terms.

In the framework of education for sustainable development, the selection of the "knowledge" component of the content of education is a mandatory step, since it helps to prevent the blurring of its subject matter and turning it into simple information about the problems of sustainable development [5].

The purpose of the study is to study the state of the issue of the formation of value ideas in students by means of the subject "Biology".

Object of research: value ideas of students. Subject of research: factors in the formation of value representations of students by means of the subject "Biology".

In order to study the current state of the issue of values formed by means of school biology at this stage of the development of natural science, and more specifically, biological school education in the context of the idea of sustainable development, we conducted a study. During it, it was planned to establish a majority structure of values formed by participants in the educational process in primary and high school; identify the factors of its formation.

\section{Technique and methods}

The study included theoretical and experimental stages.

The theoretical stage was aimed at solving the following problems:

1) to distinguish between the categories of "value", "value representations of the individual", "value 
potential of the subject", "value potential of basic science";

2) to differentiate the value representations of a personality according to the subjects of the educational process into "value representations of a student" and "value representations of a teacher";

3) to simulate the process of forming value ideas of students in the framework of the subject.

Methods used at the theoretical stage: analysis of scientific publications concerning formation of students' value ideas, according to the methodology for evaluating the value ideas of an individual.

For the experimental stage, we developed a pollquestionnaire. It included questions to study respondents' attitudes to 11 value categories that belong to two types [11]: terminal (life, health, beauty, nature, equality) and instrumental values (kindness, striving for truth, freedom, perseverance, justice, creative an approach).

The questionnaire was designed for future biology teachers, whom we consider as a connecting element in the process of transforming the value potential of a subject into value ideas of students. In 2019, 40 students of the Pedagogical University of the specialty "Biology" took part in the survey. The questionnaire was aimed at solving such problems:

1) to establish the majority structure of the school biology course values (poll questions 1, 2, 3, 7, 8, 9);

2) to establish the majority structure of the value representations of future biology teachers (poll questions $4,5,6)$.

\section{Results}

\subsection{The results of the theoretical stage of the study}

We adhere to the approach according to which value is "a firm conviction that a certain mode of behaviour or the ultimate goal of existence is preferable from a personal or social point of view than the opposite way of behaviour, or the ultimate goal of existence" [12].

Values have a hierarchical nature, because, unlike norms, they are a system: a personal system of values, a system of values of a society, a professional system of values [9]. The hierarchical structure of values also determines that the value system itself should reflect the general properties of hierarchical systems [9]. Speaking about the concrete-applied significance of axiology in the school educational process, and therefore about the concrete embodiment of the idea of sustainable development in education, it is important to solve a number of issues. For example, should a system of values formed by means of a subject of biology, chemistry, ecology reflect the properties of biological, chemical, ecological systems? Or should one proceed from such general properties of systems as integrity, emergence, subordination, reliability, adaptability, etc., irrespective of subject matter?

In the latter case, the value systems formed in the educational process when studying different educational subjects of the natural science cycle are characterized by the same properties with different content. More specifically, the problem can be formulated as follows: are terminal values such as life, health, nature - the values formed by the means of all subjects of the natural science cycle or only biology?

The study of this question will give an answer about what values, value ideas should be formed in the light of implementation of the idea of sustainable development in education when studying the subjects of the natural science cycle individually and as a whole. Let us note that there are successes in finding the answer to this question. Education for sustainable development should be subject-related $[5 ; 10 ; 13]$. Within each subjectoriented invariant (ecologically-centred, economicallycentred) a varied content is built taking into account the local educational and cultural context. The subjectivity of education for sustainable development helps to prevent the blurring of topics identified by UNESCO as priority within the main topics of discussion in education for sustainable development [14].

In the model constructed around the "ecological imperatives" invariant, the personal meanings of the ecological imperative are the system-forming factor in the content of education for sustainable development [5].

We found that in literature the concepts of "values", "value orientations", and "value representations" are often confused. The latter are not reducible either to values, as really acting immanent regulators of human activity, or to value orientations, as conscious representations of a subject about his own values.

Value representations of a personality are a complex dynamic category, including its value orientations, value ideals, value stereotypes, value retrospective, etc. [12].

The valuable potential of an educational subject is the subject content, which reveals the social and personal significance of the material being studied.

The valuable potential of basic science is the totality of objective knowledge about social and natural reality, the leading motive for which is the need to know nature, rather than gaining control over natural objects [15].

In the course of solving the second and third tasks, we came to the conclusion that:

- teacher's value ideas are factors of the formation of students' value ideas;

- formation of teacher's value ideas that are adequate to the modern level of science, society and culture development, is one of the tasks of his professional training;

- the process of forming students' value ideas within the framework of a school subject looks like this: "value potential of basic science" $\rightarrow$ factors of selecting the content of education $\rightarrow$ "value potential of a school subject" $\rightarrow$ "value ideas of a teacher" $\rightarrow$ "value ideas of a student".

\subsection{The results of the experimental stage of the study}

The content and results of a survey conducted at the experimental stage are given below (Fig. 1-4). 
1. Do you agree that the content of the subject "Biology" is aimed at the formation of value ideas of students?

Results: a) clearly "yes" - 63\%; b) more likely "yes" than "no" - 28\%; c) rather "no" than "yes" - 9\%; d) clearly "no" $-0 \%$.

2. Is the content of the subject "Biology" in the basic school, in your opinion, aimed at forming ideas about what values? Arrange them in descending order: kindness, life, health, aspiration for truth, beauty, nature, freedom, equality, perseverance, justice, creativity.

Results: nature $-86 \%$, life $-74 \%$, health $-74 \%$, beauty $-20 \%$, creativity - 6\%, freedom - 6\%, kindness $-6 \%$, equality $-3 \%$, striving for truth $-3 \%$, perseverance $-3 \%$, justice $-3 \%$.

3. What values creating is the content of the subject "Biology" in high school, in your opinion, aimed at? Arrange them in descending order (the options are the same as in question number 2).

Results: health $-54 \%$, life $-49 \%$, perseverance $46 \%$, nature $-40 \%$, striving for truth $-17 \%$, beauty $11 \%$, equality $-11 \%$, creativity $-9 \%$, justice $-9 \%$, freedom $-6 \%$, kindness $-3 \%$.

The results of the answers to questions 2 and 3 are summarized in figures 1,2 and 3 (dark line - basic school results, light line - high school results).

4. Arrange the values in order of decreasing their priority for yourself (the options are the same as in question No. 2).

Results$^{*}$ : life - health - nature - perseverance justice - equality - freedom - beauty - kindness creativity - striving for truth.

5. Select three synonyms for the word "valuable" from the list: expensive, long-awaited, deserved, promising, useful, pleasant, fair.

Results: expensive - 49\%, long-awaited - 31\%, welldeserved $-37 \%$, promising $-29 \%$, useful $-60 \%$, pleasant $-20 \%$, fair $-20 \%$ (results are presented in figure 4).

6. Rate the following statements (I agree with - the "+" sign, I do not agree with - the "-_" sign):

a) valuable is what is important and useful for me $86 \%$;

b) valuable is what is important and useful for my loved ones $-86 \%$;

c) valuable is that which is important and useful for society $-74 \%$;

d) valuable is that which is important and useful for nature $-94 \%$.

7. Arrange in order of decreasing significance the factors of influence on the formation of the student's value ideas: friends; society; the content of the educational material (information from the history of science: famous personalities, their lives, views, successes, history of discoveries); a family; school (teacher).

Results $^{*}$ : family - friends - school (teacher) - society - content of educational material.

8. What do you think is the object of value meanings in modern school biological education in general: society, nature, people.
Results: a) society $-9 \%$; b) nature $-62 \%$; c) people $29 \%$.

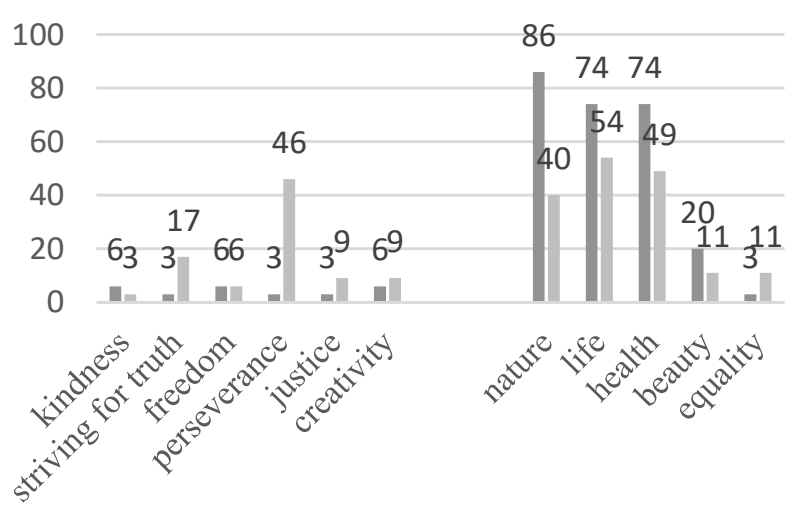

Fig. 1. General results on the selection of values of a school biology course.

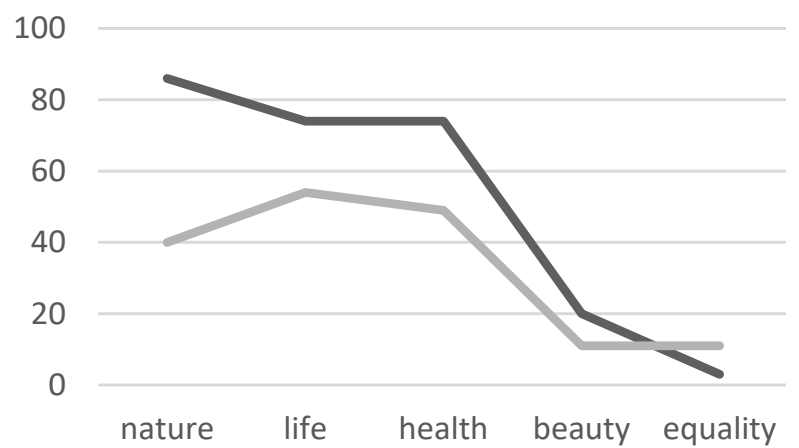

Fig. 2. Majority system of terminal values.

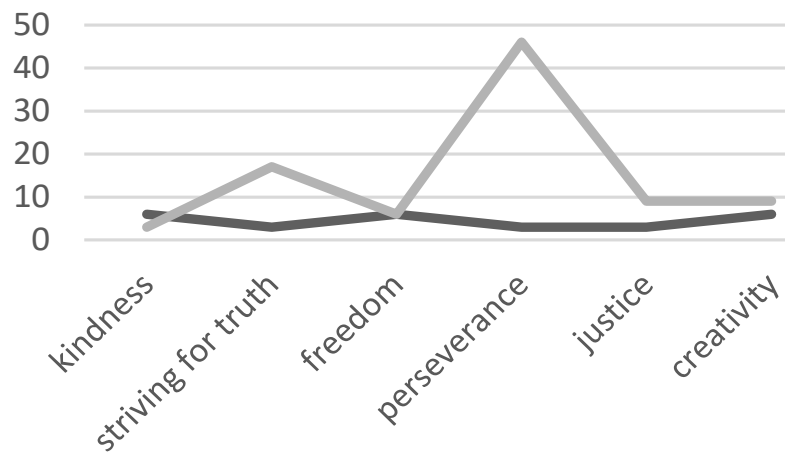

Fig. 3. Majority system of instrumental value.

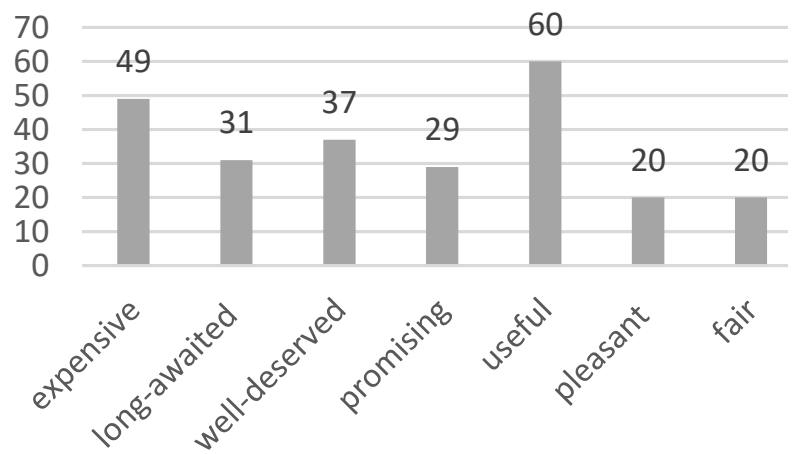

Fig. 4. The respondents' choice of synonyms for the word "valuable". 
9. Arrange the objects of value meanings in order of decreasing importance for humanity as a whole: a) society; b) nature; c) a person.

Results: nature - man - society - 40\%; man - nature - society - 26\%; man - society - nature - $17 \%$; nature society - man $-14 \%$; society - man - nature $-3 \%$; society - nature - man $-0 \%$.

* Note: the answers are ranked according to the principle of majority, that is, the correspondence of the significance of the value to the frequency of its choice from the most significant category to the least significant one.

\section{Conclusions}

1. In the basic school, the content of school biology is primarily aimed at the formation of ideas about terminal values - "life", "health", "nature".

2. In high school, the content of the subject is primarily aimed at the formation of ideas about terminal values - "life", "health", as well as instrumental value "perseverance".

3. In the biology course of high school, as compared with the basic one, the orientation toward the formation of ideas about the terminal values of "life", "health", and "nature" decreases.

4. In high school, the focus is on the formation of ideas about instrumental values "striving for truth" and "perseverance."

5. In general, the school biology course is more focused on the formation of ideas about terminal values than instrumental ones.

6. The results can be considered as confirmation of the chronological principle of building a system of values in ontogenesis.

7. In the majority structure of value ideas of future biology teachers, the three leaders are orientations towards terminal values: life, health, nature.

In the course of an experimental study, it was found that such instrumental values as a creative approach and the aspiration for truth do not find a worthy representation in the majority list of value ideas of respondents.

On the one hand, such a result is relevant, on the other hand, it is not very charitable from the point of view of a positive assessment of the readiness of future teachers for professional activities for the implementation of sustainable development ideas in biology education.

The majority structure of the selected synonymous terms (task 5) demonstrates that the respondents attribute to values the following: firstly, something having a utilitarian focus (valuable - useful), secondly, something which is expressed in significant material equivalent, and thirdly, something which involves the application of certain efforts.

\section{Outlook}

Further areas of research we see in:
- establishing the causes of the revealed differences between the value potential of the subject "Biology" and the value ideas of the participants in the educational process, that is, between their declared and real values; - elucidation of the nature of reflection of differences in the fulfilment by teachers of biology of professional activities in the framework of education for sustainable development;

- the study of the ratio of declared and real values (value ideas) of students;

- study of the microstructure of personality value representations of a biology teacher and a student studying biology (value orientations, value stereotypes, value ideals, etc.);

- modelling the process of value ideas formation of a biology teacher as a factor in the formation of students' value ideas solving the problems of education for sustainable development;

- modelling the process of forming value representations of students' personality by means of school biology in the framework of education for sustainable development.

\section{References}

1. V.A. Grachev, I.V. Ursul, A.D. Ursul, T.A. Ursul, A.I. Andreev, Obrazovanie dlya ustojchivogo razvitiya $v$ Rossii: problemy $i$ perspektivy (ekspertno-analiticheskij otchet) (Education for Sustainable Development in Russia: Problems and Prospects (Expert and Analytical Report). (Moscow, 2017)

2. Incheon Declaration: Education 2030: Towards Inclusive and Equitable Quality Education and Lifelong Learning for All (World Education Forum, Incheon, Korea R, 2015). https://unesdoc.unesco.org/ark:/48223/pf000023381 3. Accessed 14 Feb 2020.

3. N.I. Koryakina, Siberian Pedagogical Journal 6, 131 (2012)

4. G.M. Abdurakhmanov, G.A. Monakhova, L.Z. Murzakanova, L.G. Abdurakhmanova, A.A. Bagomaev, Z.A. Aliyev, South of Russia: ecology, development 2, 251 (2010).

5. E.N. Dzyatkovskaya, A.N. Zahlebny, Vestnik of Buryat State University 4, 3 (2016).

6. V. Kraevsky, I. Lerner (eds.), Teoreticheskie osnovy soderzhaniya obshchego srednego obrazovaniya (Theoretical foundations of the content of general secondary education). (Moscow, 1981)

7. H. Knyazeva (ed.), Innovacionnaya slozhnost' (Innovative complexity). (St. Petersburg, 2016)

8. E.V. Levashko, O.V. Malyarchuk, Biology at school 1, 28 (2012)

9. D.A. Sevastyanov, A.R. Gaynanova, Philosophy of Science 3, 3 (2011)

10. M.V. Ryzhakov, Dissertation, Institute of General Secondary Education of the Russian Academy of Education, 1999 
11. M. Rokeach (ed.), Understanding Human Values. Individual and Societal (Free Press, New York, 1979)

12. D.A. Leontiev, Psychological Review 1, 13 (1998)

13. E.O. Ivanova, I.M. Osmolovskaya (eds.), Predmetnost' obucheniya $v$ shkol'nom obrazovatel'nom processe (The subject of instruction in the school educational process). (Moscow, 2012)

14. The UN Economic Commission for Europe Strategy for Education for Sustainable Development (UN Economic and Social Council, 2005). https://www.unece.org/fileadmin/DAM/env/docume nts/2005/cep/ac.13/cep.ac.13.2005.3.rev.1.r.pdf. Accessed 14 Feb 2020

15. S.V. Vlasova, Russian humanitarian journal 6, 443 (2014) 